\title{
STATUS OF NORMATIVE BASE, CERTIFICATION AND ATTESTATION OF WELDING CONSUMABLES IN UKRAINE
}

\author{
N.A. PROTSENKO \\ E.O. Paton Electric Welding Institute, NASU \\ 11 Bozhenko Str., 03680, Kiev, Ukraine. E-mail: office@paton.kiev.ua
}

\begin{abstract}
Membership in the World Trade Organization and preparation for signing of agreement with the European Union oblige Ukraine to carry out harmonization of National standards with International and European ones. Technical Committee «Welding and allied processes», created on basis of the E.O. Paton Electric Welding Institute of the NAS of Ukraine, carries out the works on harmonization of standards, determining the requirements to welding production. These requirements refer to production, testing and classification of welding consumables. A list of indicated standards is shown below.
\end{abstract}

Today Ukraine has the National Certification System (UkrSEPRO), which includes mandatory certification of products, indicated in the List of Products being subjected to mandatory certification in Ukraine, and facultative certification, determining conformity of characteristics of the products to requirements of the normative documents, which are specified by customer. Welding consumables refer to facultative UkrSEPRO System of Product Certification. A result of certification of welding consumables is a Certificate of Conformity, recognized in the countries, with which Ukraine has a bilateral agreement on mutual recognition of certification results.

\section{Covered electrodes for manual arc welding}

EN ISO 2401

EN ISO 2560

EN ISO 18275

EN ISO 636

EN ISO 1071

EN ISO 14172

EN ISO 3580

EN ISO 3581

EN ISO 6848

EN ISO 14341

EN ISO 14343

EN ISO 16834
Covered electrodes. Determination of the efficiency, metal recovery and deposition coefficient

Welding consumables. Covered electrodes for manual metal arc welding of non-alloy and fine grain steels. Classification

Welding consumables. Covered electrodes for manual metal arc welding of highstrength steels. Classification

Welding consumables. Rods, wires and deposits for tungsten inert gas welding of nonalloy and fine-grain steels. Classification

Welding consumables. Covered electrodes, wires, rods and tubular cored electrodes for fusion welding of cast iron. Classification

Welding consumables. Covered electrodes for manual metal arc welding of nickel and nickel alloys. Classification

Welding consumables. Covered electrodes for manual metal arc welding of creep-resisting steels. Classification

Welding consumables. Covered electrodes for manual metal arc welding of stainless and heat-resisting steels. Classification

Arc welding and cutting. Non-consumable tungsten electrodes. Classification

\section{Solid welding wires, solid strips and rods}

Welding consumables. Wire electrodes and weld deposits for gas shielded metal arc welding of non-alloy and fine-grain steels. Classification

Welding consumables. Wire electrodes, strip electrodes, wires and rods for arc welding of stainless and heat resisting steels. Classification

Welding consumables. Wire electrodes, wires, rods and deposits for gas-shielded arc welding of high strength steels. Classification 
EN ISO 18273 Welding consumables. Wire electrodes, wires and rods for welding of aluminium and aluminium alloys. Classification

EN ISO 18274 Welding consumables. Wire and strip electrodes, wires and rods for fusion welding of nickel and nickel alloys. Classification

ISO /CD 19288 Welding consumables. Solid wire electrodes, solid wires and rods for fusion welding of magnesium and magnesium alloys. Classification

EN ISO 21952 Welding consumables. Wire electrodes, wires, rods and deposits for gas shielded arc welding of creep-resisting steels. Classification

EN ISO 24034 Welding consumables. Solid wire electrodes, solid wires and rods for fusion welding of titanium and titanium alloys. Classification

EN ISO 24373 Welding consumables. Solid wires and rods for fusion welding of copper and copper alloys. Classification

EN ISO 24598 Welding consumables. Solid wire electrodes, tubular cored electrodes and electrode-flux combinations for submerged arc welding of creep-resisting steels. Classification

EN ISO 26304 Welding consumables. Solid wire electrodes, tubular cored electrodes and electrode-flux combinations for submerged arc welding of high strength steels. Classification

EN ISO 6848 Arc welding and cutting. Non-consumable tungsten electrodes. Classification

\section{Tubular cored electrodes}

EN ISO 17632

EN ISO 17633

EN ISO 17634

EN ISO 18276

EN ISO 12153

Welding consumables. Tubular cored electrodes for gas shielded and non-gas shielded metal arc welding of non alloy and fine grain steels. Classification

Welding consumables. Tubular cored electrodes and rods for gas shielded and non-gas shielded metal arc welding of stainless and heat-resisting steels. Classification

Welding consumables. Tubular cored electrodes for gas shielded metal arc welding of creep-resisting steels. Classification

Welding consumables. Tubular cored electrodes for gas-shielded and non-gas-shielded metal arc welding of high-strength steels. Classification

Welding consumables. Tubular cored electrodes for gas shielded and non-gas shielded metal arc welding of nickel and nickel alloys. Classification

\section{Welding consumables for hardfacing}

EN 14700

Welding consumables. Welding consumables for hard-facing

\section{Welding fluxes}

EN ISO 14171 Welding consumables. Solid wire electrodes, tubular cored electrodes and electrode/flux combinations for submerged arc welding of non-alloy and fine grain-steels. Classification

EN ISO 14174 Welding consumables. Fluxes for submerged arc welding and electroslag welding. Classification

\section{Shielding gases}

EN ISO 14175

Welding consumables. Gases and gas mixtures for fusion welding and allied processes

\section{Testing of welding consumables}

EN ISO 3690

EN ISO 6847

ISO 8249

ISO /TR 13393

EN ISO 14372

Welding and allied processes. Determination of hydrogen content in arc weld metal Welding consumables. Deposition of a weld metal pad for chemical analysis

Welding. Determination of Ferrite Number (FN) in austenitic and duplex ferriticaustenitic $\mathrm{Cr}-\mathrm{Ni}$ stainless steel weld metal

Welding consumables. Hardfacing classification. Microstructures

Welding consumables. Determination of moisture resistance of manual metal arc welding electrodes by measurement of diffusible hydrogen

EN ISO 4136

EN ISO 5173

Destructive tests on welds in metallic materials. Transverse tensile test

Destructive tests on welds in metallic materials. Bend tests 
EN ISO 17639 Destructive tests on welds in metallic materials. Macroscopic and microscopic examination of welds

EN ISO 9015-1 Destructive tests on welds in metallic materials. Hardness testing. Part 1: Hardness test on arc welded joints

EN ISO 9015-2 Destructive tests on welds in metallic materials. Hardness testing. Part 2: Microhardness testing of welded joints

EN ISO 15610 Pecification and qualification of welding procedures for metallic materials. Qualification based on tested welding consumables

EN ISO 15792-1 Welding consumables. Test methods. Part 1: Test methods for all-weld metal test specimens in steel, nickel and nickel alloys

EN ISO 15792-2 Welding consumables. Test methods. Part 2: Preparation of single-run and two-run technique test specimens in steel

EN ISO 15792-3 Welding consumables. Test methods. Part 3: Classification testing of positional capacity and root penetration of welding consumables in a fillet weld

EN ISO 14532-1 Welding consumables. Test methods and quality requirements. Part 1: Primary methods and conformity assessment of consumables for steel, nickel and nickel alloys

EN ISO 14532-2 Welding consumables. Test methods and quality requirements. Part 2: Supplementary methods and conformity assessment of consumables for steel, nickel and nickel alloys

EN ISO 14532-3 Welding consumables. Test methods and quality requirements. Part 3: Conformity assessment of wire electrodes, wires and rods for welding of aluminium alloys

\section{Requirements to quality and delivery of welding consumables}

\section{EN ISO 544}

EN 10204

EN 13479

EN ISO 14344

Welding consumables. Technical delivery conditions for welding filler materials and fluxes. Type of product, dimensions, tolerances and markings

Metallic materials. Types of inspection documents

Welding consumables. General product standard for filler metals and fluxes for fusion welding of metallic materials

Welding and allied processes. Flux and gas shielded electrical welding processes. Procurement guidelines for consumables

According to Ukrainian course for European integration, a transfer from product certification in UkrSEPRO system to verification of its conformity with technical regulations, determining the requirements for products in respect of safety and activity of human and environment as well as methods of its assessment based on these requirements, takes place at present time. The approval of conformity of products, which come under Technical regulations, is mandatory based on Ukrainian laws «On Approval of Conformity» and «On Standards, Technical Regulations and Conformity Assessment Procedures». In accordance with the Conformity Assessment Procedure, Technical regulations provide for the Conformity Assessment Modules:

\begin{tabular}{|l|l|l||}
\hline \hline Module A & \multicolumn{2}{|l||}{ Internal production control } \\
\hline $\begin{array}{l}\text { Module B } \\
\text { Type exami- } \\
\text { nation }\end{array}$ & Module C & Internal production control \\
\cline { 2 - 3 } & Module D & $\begin{array}{l}\text { Quality assurance of the } \\
\text { production process }\end{array}$ \\
\cline { 2 - 3 } & Module E & Product quality assurance \\
\cline { 2 - 3 } & Module F & Product verification \\
\hline Module G & \multicolumn{2}{|l||}{ Each unit verification } \\
\hline Module H & \multicolumn{2}{|l||}{ Full quality assurance acc. to ISO 9001 } \\
\hline
\end{tabular}

A module for performance of Conformity Assessment Procedure is chosen depending on type of product, its description and functional peculiarities, present or potential risks, necessity of participation of the third independent party in conformity assessment.

Certification procedure, based on European Directives and Technical regulations, is divided on modules (schemes of certification):

- A - internal production control, Conformity declaration;

- A1 - internal production control plus supervised product testing;

- A2 - internal production control plus supervised product checks at random intervals;

- B - type examination;

- C - conformity to type based on internal production control «Type conformity declaration»;

- C1 - conformity to type based on internal production control plus supervised product testing;

- C2 - conformity to type based on internal production control plus supervised product checks at random intervals; 
- D - conformity to type based on quality assurance of the production process;

- D1 - quality assurance of the production process;

- E - conformity to type based on product quality assurance;

- E1 - quality assurance of final product inspection and testing;

- F - conformity to type based on product verification;

- F1 - conformity based on product verification (Conformity certificate CE);

- $\mathrm{G}$ - conformity based on unit verification;

- $\mathrm{H}$ - conformity based on full quality assurance;

- H1 - conformity based on full quality assurance plus design examination.

Manufacturers of welding consumables in order to expand product markets and satisfy the consumers should fulfill the requirements of legislative and normative base of probable market.

In accordance with EN 13479 the manufacturer of welding consumables should develop, verify by documents and continuously maintain own system of plant production control (PPC) in order to guaranty that the products, proposed in the market, confirm the indicated characteristics. PPC system should consist of procedures, regular checks and tests and/or assessments and application of the results in control of raw, component materials, production process and products. Development of PPC system should be based on requirements of EN ISO 9001 and EN 12074.

It is also necessary to develop a program and carry out primary tests of indices of welding properties and characteristics based on classification of welding consumables in accordance with requirements of the standards, indicated in sections 1-5 of given above List of welding consumables. Types of tests and frequency of their performance should correspond to guidelines, given in EN ISO 544, ISO 15792-1, ISO 15792-2, ISO 15792-3, and EN 14532-1. The requirements for testing of welding consumables as well as allowable values and deviations should correspond to section 6 of EN 13479.

It is reasonable from economic point of view to carry out primary tests of welding consumables, considering the requirements of EN ISO 15610, and invite the third party for simultaneous receiving of Welding Procedure Qualification Record according to the requirements of series of standards EN ISO 15614 «Specification and qualification of welding procedures for metallic materials». At that, full complex of tests is carried out using classified grade of welding consumables and control welded joints by means of visual testing, radiographic or ultrasonic, magnetic particle or die-penetrant flaw detection, transverse tensile tests, transverse bend, impact toughness, hardness, macroscopic examination and, if necessary other tests, for examples, intercrystalline corrosion.

The results of tests listed above can be used for verification of conformity to the requirements of Technical regulations and European Directives, if welded structures were made using classified welding consumables, which are subjected to mandatory marking by National Conformity Mark or CE Conformity Mark.

The conformity marks indicate that these products were manufactured in accordance with acting Technical regulations and European Directives, and fulfill the critical requirements regarding safety of its operation and have no negative effect on environment.

Manufacturer or its authorized representative are responsible for applying of Conformity mark on welding consumable or, if it is possible, it can be marked on assembly label, package or accompanying documents for corresponding products.

Below is given the information which should be indicated on label, package and/or accompanying documents for corresponding products:

\begin{tabular}{|c|c|}
\hline $\mathrm{CE}$ & $\begin{array}{l}\text { Marking of CE conformity which } \\
\text { consists of CE symbol, given in } \\
\text { Directive } 93 / 68 / \text { EEC }\end{array}$ \\
\hline 1234 & $\begin{array}{l}\text { Identification number of } \\
\text { authorized body (if necessary) }\end{array}$ \\
\hline $\begin{array}{l}\text { AnyCo Ltd, PO Box } 21 \\
\text { B-1050 } \\
14\end{array}$ & $\begin{array}{l}\text { Name or trade mark } \\
\text { Address of manufacturer } \\
\text { Last to figures of the year, when } \\
\text { the making was made }\end{array}$ \\
\hline 1234-CPD-00234 & $\begin{array}{l}\text { Number of certificate (if } \\
\text { necessary) }\end{array}$ \\
\hline EN $13479+$ EN ISO 2560 & Numbers of European standards \\
\hline $\begin{array}{l}\text { Coated electrode } \\
\text { EN ISO } 2560- \\
\text { E46 } 3 \text { 1Ni B } 54 \text { H5 } \\
\text { Hazardous substance } \\
\ll \mathrm{x} »<\ll n » \cdot 10^{-6}(\mathrm{ppm})\end{array}$ & $\begin{array}{l}\text { Characteristics of welding } \\
\text { consumable }\end{array}$ \\
\hline
\end{tabular}

If production of welding consumables is declared, the manufacturer completes the declaration, example of which is shown in new version of standard EN 13479. 